орієнтоване навчання [Електронний ресурс] / П. П. Грабовський. - Режим доступу: http://www.zippo.net.ua/index.php?page_id=203 4. Жук О. Л. Педагогика : Учеб.-метод. комплекс для студентов пед. специальностей / О. Л. Жук. - Мн. : БГУ, 2003. - 383 с. 5. Сергеев И. С. Как организовать проектную деятельность учащихся : Практическое пособие для работников общеобразовательных учреждений / И. С. Сергеев.М. : Аркти, 2004. - 250 с. 6. Кліменко О. М. Проектно-технологічна методика як педагогічна передумова удосконалення процесу трудового навчання у загальноосвітній школі[Електронний ресурс] / О.М.Кліменко, Ю.В.Коломієць. - Режим доступу: http://www.rusnauka.com/18_EN_2009/Pedagogica/48685.doc.htm

\title{
Ігор Гороикін
}

\section{КОНЦЕПТУАЛЬНІ ЗАСАДИ ФОРМУВАННЯ МОВНОЇ ОСОБИСТОСТІ МАЙБУТНІХ ПЕРЕКЛАДАЧІВ}

Горошкін I. О. Концептуальні засади формування мовної особистості майбутніх перекладачів.

У статті представлено узагальнену точку зору на професійну підготовку майбутніх перекладачів на рівні методологічного концепту (підходи, принципи навчання), змістового (вимоги до відбору змісту навчання, соціокультурна підготовка), технологічного (провідні форми, методи, засоби навчання, організація самостійної роботи студентів).

Ключові слова: професійна підготовка, мовна особистість перекладача, концепт методологічний, змістовий, технологічний.

Горошкин И. А. Концептуальные основы формирования языковой личности будущих переводчиков.

В статье представлена обобщенная точка зрения на профессиональную подготовку будущих переводчиков на уровне методологического концепта (подходы, принципы обучения), содержательного (требования к содержанию обучения, социокультурная подготовка), технологического (основные формы, методы, средства обучения, организация самостоятельной работы студентов).

Ключевые слова: профессиональная подготовка, языковая личность переводчика, концепт методологический, содержательный, технологический.

Goroshkin I. A. The conceptual basis of the formation of linguistic identities of future interpreters.

The article presents a generalized point of view on the training of future interpeters at the professional level of methodological concept (approach, principles of teaching), substantial (requirements for the content of training, socio-cultural training), technology (the basic forms, methods and meanings of training, the organization of independent work of students).

Key words: training, language personality, interpreter methodological concept, informative, technological.

Сьогодення вимагає посилення вимог до перекладачів, які, постаючи посередниками міжкультурного спілкування, уможливлюють міжнародні контакти в багатьох галузях, без яких важко уявити сучасне суспільство. На думку дослідників (I. Бахов, Н. Гавриленко, В. Сдобников, С. Тер-Мінасова та ін.), підготовка фахівців не обмежується мовними проблемами, педагог має «навчити майбутніх перекладачів 
робити правильні переклади, підготувати їх до професійного життя, озброївши методикою перекладу, познайомивши з послідовністю дій перекладача, з необхідними для цього знаннями, уміннями й навичками, з професійними проблемами, можливими під час роботи, із зовнішніми ресурсами, які перекладач може використовувати у своїй діяльності тощо» [3, с. 3]. Отже, перекладач $є$ суб'єктом міжкультурних дій та інтеракцій, інтерперсональної, інтертекстуальної, інтердискурсивної комунікацій.

Останнім часом проблема підготовки майбутніх перекладачів знаходиться в полі зору філософів (К. Мальцева, М. Рябова та ін.), лінгвістів (І. Абдулмянова, Н. Валєєва, В. Сдобников, О. Петрова та ін.), психологів (Р. Гладушина, В. Гусєв, І. Зимня, Т. Пастрик, А. Плєхов та ін.), педагогів (Н. Гавриленко, Н. Гальскова, О. Заболотська, I. Плужник, Г. Саприкіна та ін.). Особливий інтерес викликають праці, у яких відображено результати дослідження способів формування професійної компетентності майбутніх лінгвістів і перекладачів, зокрема праці І. Бахова, Д. Іщенко, В. Калініна, Т. Колодько, О. Павлик, Т. Пастрик, 3. Підручної, К. Скиби, Н. Соболь, Ж. Таланової, Л. Тархової, О. Шупти, А. Янковця. Аспекти соціокультурної підготовки в процесі навчання іноземної мови відображено в наукових студіях Ю. Пассова, С. Тер-Мінасової, R. Lado, H. Brown, P. Erman, J. Harmer, A. D. Hirsh, J. L. Moreno, M. Wallace, A. R. Wright. Однак, попри зростання кількості публікацій, концептуальні засади формування мовної особистості майбутніх перекладачів ще не були предметом спеціального розгляду.

Мета статmі: на основі аналізу фахової літератури, узагальнення досвіду роботи вітчизняних вищих навчальних закладів окреслити концептуальні засади формування мовної особистості студентів - майбутніх перекладачів.

Дослідники вважають вторинною мовну особистість перекладача. Згідно 3 поглядом А. Плєхова, це «комунікативно активний суб' єкт, здатний тією чи тією мірою пізнавати, описувати, оцінювати, перетворювати навколишню дійсність і брати участь у спілкуванні з іншими людьми засобами іноземної мови в іншомовно-мовленнєвій діяльності» [9]. Нам імпонує концепція гармонійного перекладацького світогляду, розроблена Л. Кушніною, М. Силантьєвою. На їхню думку, перекладач, «створюючи текст для іншої мовної особистості, сам набуває рис елітарної мовної особистості, перетворюючи й удосконалюючи себе й довкілля, оточуючих людей. Вони визначають перекладача як вторинну мовну особистість, оскільки він не створює смисли, а лише транслює їх. Разом з тим у межах синергетики перекладу визнають ідею прирощення смислу, що реалізується в будь-якому якісному перекладі» [6, с. 74].

Отже, мовна особистістю перекладача - це вторинна мовна особистість елітарного типу, здатна пізнавати, описувати, оцінювати, перетворювати навколишню дійсність, ефективно спілкуватися засобами іноземної мови в іншомовній дискурсній діяльності.

Ефективне формування мовної особистості забезпечує врахування концептуальних засад, що визначають методологію, зміст і технологію професійної підготовки майбутніх перекладачів.

Конкретизуємо методологічний концепт, що відображає взаємозв'язок різних підходів, принципів навчання.

Особистісно зорієнтований підхід зумовлює стимулювання розвитку індивідуальності кожного студента, його особистісних рис, передусім через надання свободи вибору під час виконання завдань, максимальне використання персонального досвіду майбутніх перекладачів. Погоджуємося 3 думкою I. Беха, що особистісно зорієнтований підхід у навчанні асимілюється із суб'єктно-діяльнісним, компетентнісним, синергетичним, комунікативно-діяльнісним підходами, виразно 
виявляється в кожному з них, грунтуючись на механізмах свідомості й самосвідомості, сприяє формуванню ціннісних орієнтирів у різних видах діяльності [1].

Компетентнісний підхід забезпечує діяльнісну, практико-орієнтовану спрямованість навчального процесу у виші. Н. Бібік пише, що в системі освіти перехід до компетентнісно зорієнтованого навчання означає переорієнтацію 3 процесу на результат освіти в діяльнісному вимірі, розгляд цього результату 3 погляду затребуваності в суспільстві, забезпечення спроможності випускника відповідати новим запитам і потребам ринку послуг, мати відповідний потенціал для практичного розв'язання життєвих проблем, пошуку свого «я» в професії, у соціальній структурі [2, c. 49]. Як слушно зазначає I. Єрмаков, «компетентнісний підхід повинен подолати прірву між освітою і вимогами життя» [5, с. 29]. Сьогодні надзвичайно гостро стоять питання про конкретну мету навчання майбутніх перекладачів: що повинен знати i вміти фахівець, які особистісні риси мають бути в нього сформовані. Життя вимагає не просто опанування змісту комплексу навчальних дисциплін, а й сформованості у майбутніх фахівців відкритості до нових знань, мобільності, під якою розуміємо вміння швидко орієнтуватися в специфічних питаннях перекладу, ураховувати соціокультурний контекст тощо. Однак у сучасних умовах спостерігаємо тенденцію до швидкого старіння знань. Отже, утворилися суперечності між соціальними потребами і змістом, технологіями сучасної професійної освіти. Саме тому науковці відзначають необхідність переосмислення мети й завдань вищої освіти, створення умов для розвитку особистості кожного студента, розроблення технологій формування професійної компетентності майбутніх перекладачів. Упровадження компетентнісного підходу спонукає науковців до перегляду традиційних поглядів на педагогічні явища й значно розширює можливість їх інтерпретації.

Системний підхід орієнтує на виявлення й розвиток потенційних можливостей кожного студента та задоволення потреб через систему здатностей розв'язувати проблеми професійної діяльності та вміння, які відображають ці здатності, а також шляхом моделювання якісного навчання майбутнього фахівця (система професійних умінь та відповідних їм змістових модулів) [7].

Комунікативно-діяльнісний підхід забезпечує вдосконалення всіх видів мовленнєвої діяльності студентів, активне залучення їх до комунікації. У професійній підготовці майбутніх перекладачів цей підхід передбачає моделювання різноманітних комунікативних ситуацій, наближених до майбутньої перекладацької діяльності (зустріч іноземних гостей, переговори, брифінги тощо).

Соціокультурний підхід до формування мовної особистості перекладачів зумовлює наповнення навчальних дисциплін усіх блоків соціокультурним компонентом.

Професійно зорієнтований підхід спрямований на професійно-мовленнєве вдосконалення майбутніх перекладачів у різних сферах спілкування.

Нині студент вищого навчального закладу має широкий спектр можливостей професійного обміну 3 представниками інших культур, іншомовного спілкування зі своїми однолітками 3 країн, мова яких вивчається. Зусилля викладачів повинні бути об'єднані спільною метою: готовності до такого спілкування, що потребує розроблення комплексу спеціальних навчальних матеріалів.

Фундаментальні дослідження В. Лутая, О. Чалого доводять, що сучасна стратегія навчальної діяльності повинна спиратися на наукову парадигму, у центрі якої знаходиться синергетика - продуктивна міждисциплінарна теорія, що дає змогу вивчати процеси становлення й розвитку складних відкритих систем. В. Лутай зазначає, що на засадах синергетичної парадигми можна оптимізувати і діалог культур, і відповідний йому діалог освітніх систем, який, по-перше, може подолати основний недолік 
сучасного людства, тобто «перетворення чужого на вороже», по-друге, розв'язати складну проблему про те, що є позитивним у певній культурі, а тому може ввійти як унікальний внесок у розвиток сучасного суспільства, а що є негативним, тобто потребує ліквідації [8].

Аналіз наукових студій у галузі теорії й методики професійної освіти (І. Бахов, Н. Гавриленко, С. Перова, І. Плужник, В. Сафонова, С. Шехавцова та ін.) дозволив дійти висновку, що особливо значущими для формування мовної особистості майбутніх перекладачів $є$ комплекс принципів. Розглянемо їх докладніше.

Принцип гуманізації навчального процесу й особистісної орієнтації спрямований на визнання цінності людини як особистості, повагу іiі прав і свобод, зорієнтований на загальнолюдські цілі й цінності.

Принцип системності й послідовності дає змогу представити процес формування мовної особистості майбутнього перекладача як цілісну динамічну систему, що забезпечує єдність навчання, розвитку, виховання й характеризується стійкими взаємозв’ язками між цими складниками.

Принцип розвивального й виховуючого навчання виражає провідну мету функціонування педагогічної системи, він пов'язує основні педагогічні категорії (виховання, навчання, освіту).

Принцип фундаментальності освіти та іï професійної спрямованості вимагає правильного співвідношення орієнтації на широку ерудицію та вузьку спеціалізацію, фундаментальність і технологічність у процесі підготовки і в результатах навчання, загального розвитку особистості й розвитку професійної компетентності майбутніх перекладачів.

Принцип свідомості і творчої активності студентів зумовлює забезпечення викладачем умов, що стимулюють активність студентів, спонукають їх до іншомовної комунікації, максимально розкривають їхні творчі здібності за допомогою використання відповідних форм, методів і засобів навчання - дидактичних ігор, уявних телемостів, презентацій, обговорень тощо.

Принцип послідовності забезпечує перехід від простих форм і методів роботи до більш складних - креативних, що потребують творчого мислення й самостійності, від простих адаптованих текстів до автентичних, оригінальних текстів іноземною мовою.

Принцип науковості передбачає орієнтацію на новітні розробки, передусім у галузі педагогіки, психолінгвістики, етнопсихології, а також теорії комунікації та міжкультурної комунікації. Надзвичайно важливо створити умови для формування в студентів наукових понять, що відіграють велику роль у становленні мовної особистості перекладача.

Особливої значущості набуває принцип поєднання навчання з життям. Атмосферу, максимально наближену до життя, забезпечує використання автентичних іншомовних наочних засобів, а також текстів, що стимулюють студентів до різних видів мовленнєвої діяльності.

Принцип контекстності допомагає «занурити» навчальний процес у контекст майбутньої перекладацької діяльності передусім через моделювання професійно значущих ситуацій, переклад професійно орієнтованих текстів, що наповнює процес формування мовної особистості майбутніх перекладачів особистісним смислом, розвиває позитивну мотивацію студентів, зумовлює їхню активну життєву позицію.

Принцип соціокультурної відповідності зумовлений тим, що останнім часом у мовній освіті акцент зміщується в бік формування професійної міжкультурної компетентності. Зміст навчального матеріалу має не тільки забезпечити студентів можливістю оволодіти ще одним способом навчання, але й зануритися в нову культуру. 
Посилення соціокультурного та міжкультурного компонента повинно стати важливим критерієм відбору змісту навчального матеріалу.

Принцип реалізації міжпредметних зв'язків спонукає викладачів і студентів до творчої діяльності. Джерелом розвитку інтересу до вивчення іноземної мови можуть стати міжпредметні зв'язки в навчанні, особливо зв'язки мови з літературою, історією, географією, образотворчим мистецтвом, музикою.

Принцип діалогу культур передбачає компаративне вивчення культур у контексті їхнього безпосереднього й опосередкованого взаємовпливу.

Принцип креативності спрямовує на залучення студентів до творчої діяльності, що забезпечує підвищення рівня їхньої мовленнєвої, соціокультурної компетентностей.

Реалізація принципу наочності має своєрідні ознаки: наочність (фільми, слайди, телепередачі, презентації, фотографії, малюнки, репродукції тощо); є важливим засобом посилення мотивації студентів.

Принцип поєднання індивідуальних і колективних форм навчання зумовлює оптимальне співвідношення різних форм навчання.

У процесі формування мовної особистості майбутніх перекладачів варто враховувати також принципи, що увиразнюють сутність компетентнісного підходу, який останнім часом є провідним в організації професійної освіти. До них належать принципи мотиваційного забезпечення навчального процесу; ціннісного орієнтування; життєвої доцільності й дієвості знань; спрямування навчання на всебічний i гармонійний розвиток; співробітництва і взаємної підтримки; активності особистості; індивідуалізації; органічної єдності людини, мовлення і процесу навчання.

Принципи завжди органічно взаємопов'язані, доповнюють й зумовлюють один одного. Вони підтверджені змістом навчання (реалізовані в програмах і підручниках) та покладені в основу навчального процесу: організації аудиторної, позааудиторної, самостійної роботи студентів, застосування методів і прийомів навчання, добору дидактичного матеріалу тощо. Урахування сукупності схарактеризованих принципів у процесі професійної підготовки сприяє формуванню мовної особистості майбутніх перекладачів.

Важливим індикатором сформованості мовної особистості перекладача є професійна компетентність, структура якої є синтетичною, оскільки утворює єдність теоретичної й практичної готовності, а також характеризується сформованістю особистісних якостей. Практична готовність перекладача виражається в зовнішніх (предметних) уміннях. Це зумовлює виокремлення ще двох концептів формування мовної особистості перекладача - змістового й технологічного.

Змістовий концепт визначає критерії вибору змісту навчання майбутніх перекладачів, під яким розуміється сукупність загальних і спеціальних знань. Однак наявні, але не використані знання залишаються нікому не потрібними. Зміст навчання має бути узгодженим 3 вимогами ОКХ, ОПП. Саме тому важливим, на наш погляд, $є$ звернення до теоретичної діяльності як форми теоретичної готовності, у структурі якої можна виокремити аналітичні, прогностичні, проективні та рефлексивні вміння. Для перекладача надзвичайно важливим є формування всіх груп умінь.

Реалізація змістового концепту пов'язана з визначенням форм, методів, засобів, що забезпечували б реалізацію мети й завдань навчання. Це спонукає нас до розгляду технологічного концепту формування мовної особистості майбутніх перекладачів, а в межах нього - форм, методів, прийомів, засобів навчання.

Відповідно до ст. 43 Закону України «Про вищу освіту» навчальний процес у вищих навчальних закладах здійснюється в таких організаційних формах: навчальні заняття, самостійна робота, практична підготовка, контрольні заходи [6]. Історично 
склалося, що провідною формою організації навчальних занять у вищих закладах освіти $\epsilon$ лекція, призначення якої полягає в тому, щоб допомогти студентам опанувати теоретичний матеріал 3 дисципліни. Лекція $є$ своєрідною точкою відліку для всіх організаційних форм і самостійної роботи студентів. Правильно побудована лекція дає стимул дослідницькій діяльності студентів. Поділяємо думку О. Семеног: «Дія лекційного матеріалу повинна стимулювати і розвивати, власне, передусім не систему знань, а мислення і навички самостійної дослідницької роботи» [10, с. 113]. Останнім часом лекція істотно змінилася, передусім через використання можливостей мультимедійних засобів навчання. Викладачі застосовують довідковий та анімаційний матеріал, що дозволяє доповнити виклад матеріалу, збільшити емоційний вплив на студентів.

Практичне заняття - така форма навчання, під час якої студентам надається змога застосувати отримані ними знання в практичній діяльності. 3 визначення випливає, що мета практичних занять полягає у формуванні стійких умінь і навичок студентів, закріпленні знань. Ця форма навчання відрізняється від інших типів меншою його регламентацією й більшою самостійністю студентів.

Особлива роль у професійній підготовці майбутніх перекладачів належить самостійній роботі, під якою розуміємо діяльність студентів, що організована ними самостійно, спрямована викладачем, проте відбувається без участі останнього.

Ефективність формування майбутніх перекладачів значною мірою залежить від розуміння сутності форм, методів, прийомів, засобів навчання, правильного їх добору й ефективного застосування. Одним із ключових компонентів навчального процесу $є$ метод, тобто той механізм, що приводить у дію його зовнішні і внутрішні резерви. Важливо добирати і впроваджувати такі методи навчання, що забезпечать високий рівень пізнавальної активності студентів, ефективність і результативність навчальної діяльності. Важливою умовою ефективності процесу навчання $є$ вміле поєднання різних методів. Високі результати, як свідчить аналіз наукових студій, дають комплексні цикли, що містять традиційні й інноваційні методи і форми.

Отже, концептуальні засади формування мовної особистості майбутніх перекладачів зумовлені впровадженням трьох взаємопов'язаних концептів, що сприяють реалізації провідної ідеї дослідження. Методологічний концепт відображає взаємозв’язок підходів, принципів професійної підготовки майбутніх перекладачів. Змістовий - визначає розроблення змісту навчання студентів 3 урахуванням сучасних вимог. Технологічний концепт передбачає проектування форм, методів, засобів навчання.

Перспективи подальших досліджень убачаємо в розробленні моделі формування мовної особистості майбутніх перекладачів.

\section{Література}

1. Бех І. Д. Особистісно орієнтоване виховання / Іван Дмитрович Бех ; Ін-т засобів навчання. - К. : Атіка, 1998. - 204 с. 2. Бібік Н. М. Компетентністний підхід: рефлексивний аналіз застосування / Надія Михайлівна Бібік // Компетентністний підхід у сучасній освіті : світовий досвід та українські перспективи / за заг. ред. О. В. Овчарук. - К. : К.І.С., 2004. - С. 47-52. 3. Гавриленко Н. Н. Теория и методика обучения переводу в сфере профессиональной коммуникации / Н. Н. Гавриленко. - Кн. 1. - М. : Науч.-техн. о-во имени акад. С. И. Вавилова, 2009. - 178 с. 4. Закон України «Про вищу освіту». - Харків: КСИЛОН, 2002. - С. 40; 50-51. 5. Компетентнісний підхід у неперервній освіті : [кол. монографія]/ за наук. ред. І. Г. Срмакова. - Донецьк: Каштан, 2012. - 260 с. 6. Кушнина Л. В. Языковая личность переводчика в свете концепции переводческого пространства [Електронний ресурс]/ Л. В. Кушнина, 
М. С. Силантьева // Вестник Пермского университета. Российская и зарубежная філология. - 2010. - Вып. 6(12). - С. 71-75. - Режим доступа к журн.: http://www.rfp.psu.ru/archive/6.2010/kushnina_silantjeva.pdf 7. Лозова В. I. Педагогічні цінності сучасної освіти / Валентина Іванівна Лозова // Педагогічна і психологічна наука в Україні : зб. наук. пр. до 15-річчя АПН України : у 5 т. - К. : Пед. думка, 2007. - Т. 1. Теорія та історична педагогіка. - С. 68-79. 8. Лутай В. С. Синергетична парадигма як філософсько-методологічна основа формування світоглядів XXI століття / В. С. Лутай // 3б. наук. праць. - Вип. 3; за заг. ред. В. А. Андрущенка. - К. : Знання, 2000. - 244 с. 9. Плехов А. Н. Психологические условия развития вторичной языковой личности преподавателя-лингвиста : автореф. дис. на соискание ученой степени канд. психол. наук / А. Н. Плехов. - Н.Новгород, 2007. - 23 с. 10. Семеног О. Академічна лекція як професійний комунікативний феномен / О. Семеног // Естетика і етика педагогічної дії: зб. наук. пр./ Інститут педагогічної освіти i освіти дорослих НАПН України; Полтавський національний педагогічний університет імені В. Г. Короленка. - Вип. 1. К. ; Полтава : ПНПУ ім. В. Г. Короленка, 2011. - С. 113-121.

УДК $37.025+159.942$

Ірина Дишлева

\section{РОЗРОБЛЕННЯ ПРОБЛЕМИ ЗБЕРЕЖЕННЯ І ЗМІЦНЕННЯ ЗДОРОВ'Я УЧНІВ В УМОВАХ ЗАГАЛЬНООСВІТНЬОГО НАВЧАЛЬНОГО ЗАКЛАДУ}

Дишлева I. М. Розроблення проблеми збереження і зміцнення здоров'я учнів в умовах загальноосвітнього навчального закладу.

У статті розкрито стан розроблення проблеми впровадження здоров'язбережувальних технологій у навчально-виховний процес загальноосвітнього навчального закладу. Здійснено грунтовний аналіз нормативно-правової бази щодо організаційно-методичного забезпечення у процесі застосування здоров' язбережувальних технологій.

Ключові слова: здоров'я, здоров'язбережувальні технології, загальноосвітній заклад, учні основної школи.

Дышлева И. Н. Разработка проблемы сбережения и укрепления здоровья учеников в условиях общеобразовательного учебного заведения.

В статье раскрыто состояние разработки проблемы внедрения здоровьесберегающих технологий в учебный процесс общеобразовательного заведения. Произведен глубокий анализ нормативно-правовой базы касательно организационнометодического обеспечения в процессе применения здоровьесберегающих технологий.

Ключевые слова: здоровье, здоровьесберегающие технологии, общеобразовательное заведение, ученики основной школы.

Dyshleva I. N. Development problems and strengthening health savings in terms of general education students academic institutions.

The article reveals the state of development problems of implementation of healthtechnologies in the educational process in secondary institution. Made a deep analysis of the legal framework regarding organizational methods in the application of health- technology.

Key words : Health, Health- technology, educational institution, primary school pupils.

Теоретичний і практичний досвід у галузі здоров'язбереження дітей переконує в доцільності здійснення грунтовного аналізу основ здоров'язбереження дітей за такими 